\title{
Adaptation of the Nursing Activities Score for oncologic care
}

\author{
Adaptação do Nursing Activities Score para assistência oncológica \\ Adaptación del Nursing Activities Score para la asistencia oncológica
}

\section{Tatiane Catleia Melo dos Santos e Silva', Meire Cristina Novelli Castro', Regina Célia Popim'}

'Universidade Estadual Paulista Júlio de Mesquita Filho, Botucatu Medical School. Botucatu, São Paulo, Brazil.

How to cite this article:

Silva TCMS, Castro MCN, Popim RC. Adaptation of the Nursing Activities Score for Oncologic Care.

Rev Bras Enferm [Internet]. 2018;71(5):2383-91. DOI: http://dx.doi.org/10.1590/0034-7167-2017-0015

\author{
Submission: 04-01-2017_Approval: 11-05-2017
}

\section{ABSTRACT}

Objective: To adapt the contents of the Nursing Activities Score (NAS) tool to assist patients with cancer. Method: Methodological research that according to the Delphi Technique is a method aiming at the validation of content through agreement of experts. Results: It took two rounds of opinion of experts, which added content contributions without modifying the structure and score of the original tool. The level of agreement ranged from 71 to $86 \%$, and biological factors and assistance were more suggested: Monitoring and controls; Laboratory investigations; Support and care for family members and patients; Intravenous replacement; Renal support; Management activities. Conclusion: A high level of complexity of patients with cancer, and the demand for care and biopsychosocial-spiritual care was diagnosed. This tool will enable the measurement of the workload of the Oncology Nursing team, which can contribute to the staffing dimensioning.

Descriptors: Cancer; Workload; Nursing Oncology; Nursing Care; Human Resources.

\section{RESUMO}

Objetivo: Adaptar o conteúdo do instrumento Nursing Activities Score (NAS) para assistência de pacientes oncológicos. Método: Pesquisa metodológica que, de acordo com a Técnica Delphi, trata-se de um método que visa validar conteúdo por meio de um consenso de experts. Resultados: Foram necessárias duas rodadas de opinião de especialistas, os quais acrescentaram contribuições de conteúdo sem modificar a estrutura e a pontuação do instrumento original. O nível de concordância variou de 71 a $86 \%$, sendo que os fatores biológicos e assistencias sofreram mais sugestões: Monitorização e controles; Investigações laboratoriais; Suporte e cuidados aos familiares e pacientes; Reposição intravenosa; Suporte renal; Atividades gerenciais. Conclusão: Foi diagnosticado um alto nível de complexidade do paciente oncológico, além da demanda de cuidados assistenciais e biopsicossociais espirituais. Este instrumento possibilitará a mensuração da carga de trabalho da equipe de Enfermagem em Oncologia, o que pode contribuir para o dimensionamento de pessoal.

Descritores: Câncer; Carga de Trabalho; Enfermagem Oncológica; Cuidados de Enfermagem; Recursos Humanos.

\section{RESUMEN}

Objetivo: Adaptar el contenido del instrumento Nursing Activities Score (NAS) para la asistencia de pacientes oncológicos. Método: Investigación metodológica que, de acuerdo con la Técnica Delphi, se trata de un método que pretende validar contenido por medio de un consenso de expertos. Resultados: Fueron necesarias dos rondas de opinión de expertos, que añadieron contribuciones de contenido sin modificar la estructura y la puntuación del instrumento original. El nivel de concordancia varió de $71 \%$ a $86 \%$, siendo que los factores biológicos y asistenciales sufrieron más sugerencias: Monitoreo y controles; Investigaciones de laboratorio; Apoyo y cuidados a los familiares y pacientes; Reposición intravenosa; Soporte renal; Actividades gerenciales Conclusión: Se diagnosticó un alto nivel de complejidad del paciente oncológico, además de la demanda de cuidados asistenciales y biopsicosociales espirituales. Este instrumento posibilitará la medición de la carga de trabajo del equipo de Enfermería en Oncología, lo que puede contribuir al dimensionamiento del personal.

Descriptores: Cáncer; Carga de Trabajo; Enfermería Oncológica; Cuidados de Enfermería; Recursos Humanos. 


\section{INTRODUCTION}

Cancer is known as a chronic degenerative disease in which cells have a disordered growth. These, in turn, invade other tissues or even organs, spreading through the body (metastases). The different types of cancer vary according to the gender of the patient, the location of the tumor and the stage of the disease. The causes for cancer are diverse, there are extrinsic (the environment, habits, cultural and social customs) and intrinsic (genetic mutations) factors ${ }^{(1-2)}$.

Patients with cancer require specific care to cope with the disease and other conditions that involve it, such as psychological support, follow-up by a dentist for assessments of adverse reactions caused by treatment, social assistance, and nutritionist with adequate diet for reduction of adverse reactions, among others. The fulfillment of these demands is vital for the development of the treatment and the new adaptation to the disease. In specific therapy, the patient will have specific institutional protocols for each type of tumor diagnosed based on the literature and scientific evidence. Throughout the treatment, with the possible progression of the disease and/or adverse reactions, the protocol can be changed by the oncologist. In the process of caring for oncological nursing, it is up to the nurse to plan nursing actions and interventions with the patient. The administration of the antineoplastic antibiotic is the responsibility of the trained nurse, according to the Regional Nursing Council (COREN), thus, as the necessary safety equipment for administration is listed $^{(3)}$ and it is also important the care taken with the way of administration of the antineoplastic antibiotic to prevent possible extravasations, as well as the direct care of this patient.

It is needed a comprehensive care with a well-trained multidisciplinary team with specific knowledge in order to meet biopsychosocial-spiritual demands of these individuals and their families. The nursing team is in greater numbers in hospital institutions and thus provides a direct care for the patient ${ }^{(4)}$.

Currently and globally, the workload has been well discussed due to its importance in the quality of health care. The workload of the nursing team due to overwork, the day shift is one of the factors that influence the safety of the patients, bringing risks to these individuals $s^{(5)}$.

Considering the quantitative and qualitative of the nursing team, a tool to measure workload was created, the Nursing Activities Score (NAS) ${ }^{(5)}$.

The Nursing Activities Score includes subcategories divided into monitoring and controls; hygiene procedures; mobilization and positioning; support and care for the family and patients; and administrative and managerial tasks. The resulting tool presents 7 major categories and 23 items in the original version. Each item has a score, so the score assigned to a patient results from the sum of the scores of items that correspond to the needs of direct and indirect patient care. This score represents how much time the patient received from a nursing professional in the last 24 hours $^{(6)}$. Thus, if the score is 100 , it is construed that the patient requested $100 \%$ of the time of a nursing professional in his/her care in the last 24 hours. This score can reach $176.8 \%$ per patient ${ }^{(6-7)}$.

In Oncology, after a research in the literature and in the database, no tool was able to measure workload. This is an area that requires a quantitative and qualitative of personnel for satisfactory performance. The construction of a tool for this purpose can contribute to the quality of care and the safety of these patients.

\section{OBJECTIVE}

To adapt the contents of the Nursing Activities Score (NAS) to the nursing care in hospital oncology.

\section{METHOD}

\section{Ethical aspects}

The present study was approved by the Research Ethics Committee (CEP) of the Faculdade de Medicina de Botucatu - FMB (Botucatu Medical School) in April 2015. And the judges agreed to participate in the study by signing the Informed Consent Form.

\section{Study design}

This is a methodological research that, according to the Delphi Technique, aims to validate the content through agreement of experts.

\section{Delphi Technique}

It is a technique that allows obtaining the agreement of a group about a certain issue. This group consists of judges, which are professionals directly linked to the area in which the study is being developed. Anonymity of the judges' answers is important, so that there is no influence of psychological factors such as persuasion, balk to abandon assumed positions, among others ${ }^{(8-9)}$.

\section{Inclusion criteria}

\section{Preparation of the criteria for selection of judges}

Nursing professionals who met the following criteria were invited to act as judges: being a nurse and working in the area of Oncology (assistance, teaching or management), with at least 1 year of experience.

\section{Data collection}

At the first moment, there was a meeting of the researcher with the advisor and a nurse specialist in the NAS. The tool items and strategies for the adaptation process were discussed. The structure of the tool was not changed, as well as the orders of the items, which remained identical to the original. A review of the literature on the items that should be further developed, specifically on oncology care and on the NAS, was conducted. It was prepared from January 2015 to February 2016.

From the tool already reviewed, in its first version, this was presented to the judges initially via email in the first round. The specialists answered the researcher individually and obtained suggestions and the level of agreement. Ten judges participated.

Based on the judges' suggestions, the items were reviewed and the second version of the tool was formulated. According to Beaton et al. ${ }^{(10)}$, we could close the study stages, but, according to the researchers' decision, the second version was sent back to the experts. 
In this second round of the evaluation, we had a return rate of $70 \%$ and it was in the period from May to September 2016. We reviewed the suggestions of the judges and based on the review of the literature by the researcher, the final version of the tool was formulated. As in the first step, the tool structure was not changed, as well as the order of the items, which remained the same as the original. A descriptive analysis of the study data was carried out.

\section{RESULTS}

The Nursing Activities Score (NAS) is a validated tool for measuring the workload of nurses in Intensive Care Units. However, the tool requires complements to make it feasible in the care of patients with cancer.
In this study, ten (10) judges participated, the median was 52 years and eight $(80 \%)$ of these professionals were female. Five $(50 \%)$ were related to direct patient care, another $2(20 \%)$ to care and management, $1(10 \%)$ to care and education, $1(10 \%)$ to management and $1(10 \%)$ to more than one option. As for the time of experience, it was possible to verify that the majority of them (6) $(60 \%)$ had more than 10 years of professional experience in the area of assistance, teaching or research in Oncology.

We present the final version of the content tool adapted for oncology nursing assistance. Content adaptation was highlighted in italics.

Both rounds were suggested changes on the score and some items that would modify the structure of the NAS. However, it was not considered to make such changes, since the research is an adaptation according to the NAS concepts already established.

Chart 1 - Final version of the Nursing Activities Score for Oncology, Botucatu, São Paulo State, Brazil, 2016

\begin{tabular}{|c|c|c|}
\hline Basic Activities & Score & $\begin{array}{c}\text { Concordance } \\
\text { Level } \%\end{array}$ \\
\hline \multicolumn{3}{|l|}{ Monitoring and control } \\
\hline $\begin{array}{l}\text { - Vital time savings, calculation and regular recording of the water balance. } \\
\text { Patients are considered to be stable from a respiratory, neurological and hemodynamic point of view and } \\
\text { perform routine checks. Vital signs of specific drugs that may be cardiotoxic or hypotensive, such as pacli- } \\
\text { taxel and etoposide, and in blood transfusions. }\end{array}$ & 4.5 & 100 \\
\hline $\begin{array}{l}\text { - Presence at the bedside and observation or continuous activity for } 2 \text { hours or more in any shift for safety, } \\
\text { severity or therapy reasons such as: non-invasive mechanical ventilation, weaning, restlessness, mental con- } \\
\text { fusion, prone position, donation procedures of organs, preparation and administration of fluids or medica- } \\
\text { tion and aid in specific procedures. } \\
\text { It is considered a patient specifically receives antineoplastic antibiotic, pain evaluation, environment/ } \\
\text { comfort, anxiety, temperature control, cardiac monitoring, daily weight assessment, difficult venous access, } \\
\text { administration of irritants or blister agents, which require direct supervision, salinization of catheters and } \\
\text { follow-up of biopsies performed at the hospitalization unit. }\end{array}$ & 12.1 & 100 \\
\hline $\begin{array}{l}\text { - Presence at the bedside and observation or continuous activity for } 4 \text { hours or more in any shift, for rea- } \\
\text { sons of safety, severity, therapy, such as the examples above. } \\
\text { Patients are considered to be those need extravasation of antineoplastic antibiotics (blister agents), patients } \\
\text { with hemodynamic instability or immediate and exacerbated effects of chemotherapy, transfusion reac- } \\
\text { tions. Fatigue, peripheral neuropathy, hands and feet syndrome, anorexia, nausea/vomiting, anxiety and } \\
\text { among others are adverse reactions of chemotherapy. }\end{array}$ & 19.6 & 85.7 \\
\hline Laboratory investigations & 4.3 & 71.4 \\
\hline \multicolumn{3}{|c|}{$\begin{array}{l}\text { - Biochemical and microbiological } \\
\text { Platelet counts, erythrocytes, leukocytes, neutrophils check and search for tumor markers in possible relapse/disease progression and } \\
\text { collection (feces, urine, secretions and cultures). }\end{array}$} \\
\hline \multicolumn{3}{|l|}{ Medication - except vasoactive drugs } \\
\hline $\begin{array}{l}\text { Any type of drug, psychotropic, antineoplastic antibiotics, irritants and blisters, monoclonal antibody, an- } \\
\text { tiemetics and opioids, except vasoactive drugs, antibiotics, antifungals, growth factors, interferon, chemo- } \\
\text { therapy installation regardless of frequency and amount or way of administration. }\end{array}$ & 5.6 & 100 \\
\hline \multicolumn{3}{|l|}{ Hygiene proceduress } \\
\hline $\begin{array}{l}\text { - Carrying out hygiene procedures, such as: changing wound dressings, changing bedding, patient hygiene } \\
\text { in special situations (incontinence, burns, secreted wounds, complex surgical dressings with irrigation) and } \\
\text { special procedures isolation). } \\
\text { Patients are considered to be those with skin lesions (oncological or not) and/or surgical incision, intra- } \\
\text { venous catheters (short and long term), ostomy care (exchange of pouch, dressing and skin care), dressing } \\
\text { change, emesis of implantable or semi-implantable or peripheral central catheter dressing, eg Port-a-Cath } \\
\text { or Hickman, Broviac, Intracath and PICC. }\end{array}$ & 4.1 & 100 \\
\hline
\end{tabular}


Chart 1

\begin{tabular}{|c|c|c|}
\hline Basic Activities & Score & $\begin{array}{l}\text { Concordance } \\
\text { Level \% }\end{array}$ \\
\hline $\begin{array}{l}\text { - Carrying out hygiene procedures that last more than } 2 \text { hours in any shift. } \\
\text { Patients are considered to be those present acute emesis and/or diarrhea with or without bleeding, contact } \\
\text { precaution, droplets and aerosols. }\end{array}$ & 16.5 & 100 \\
\hline $\begin{array}{l}\text { - Carrying out hygiene procedures that last more than } 4 \text { hours in any shift. } \\
\text { Patients are considered to be those present late emesis and/or diarrhea with or without bleeding. }\end{array}$ & 20.0 & 100 \\
\hline Care with drains - all of them (except gastrostomy tube) & 1.8 & 100 \\
\hline \multicolumn{3}{|l|}{ Mobilization and positioning } \\
\hline \multicolumn{3}{|c|}{$\begin{array}{l}\text { Including procedures such as: change of position, patient mobilization; transfer of the bed to the chair, mobilization of the patient with } \\
\text { the team (e.g, immovable patient, traction, prone position). }\end{array}$} \\
\hline $\begin{array}{l}\text { - Performing the procedure (s) up to } 3 \text { times by nursing professional within } 24 \text { hours. } \\
\text { Patients are considered to be those needs help to move, get out of bed, help in positioning to feed, etc. }\end{array}$ & 5.5 & 100 \\
\hline $\begin{array}{l}\text { - Performing the procedure (s) more than } 3 \text { times or with } 2 \text { nursing professionals, at any frequency, within } 24 \text { hours. } \\
\text { Patients are considered to be those need mechanisms for positioning (ramp, bed sheet, restraint, bed transfer). }\end{array}$ & 12.4 & 100 \\
\hline $\begin{array}{l}\text { - Performing the procedure (s) with } 3 \text { or more nursing professionals, at any frequency, within } 24 \text { hours. } \\
\text { Patients are considered to be those need mechanisms for positioning (ramp, sheet, restraint), who are } \\
\text { under the effect of drugs of the sedative or opioid type, and who are obese, elderly and/or bedridden. }\end{array}$ & 17.0 & 100 \\
\hline \multicolumn{3}{|l|}{ Support and care for family and patients } \\
\hline \multicolumn{3}{|c|}{$\begin{array}{l}\text { Including procedures such as phone calls, interviews and counseling. } \\
\text { Frequently, support and care, either to the family or to the patient, allow the team to continue with other nursing activities (e.g, commu- } \\
\text { nication with the patient during hygiene procedures and communication with relatives, while at the bedside observing the patient, clari- } \\
\text { fication as to the procedures to be performed by the team, presentation of the unit, norms and routines to the patient and their relatives). }\end{array}$} \\
\hline $\begin{array}{l}\text { - Support and care for family members and patients who require exclusive dedication for about an hour on any shift, } \\
\text { such as: explaining clinical conditions, coping with pain and distress, and coping with difficult family circumstances. } \\
\text { Patients and their families are considered as those present anxiety and/or doubts of the patient in the face of therapy } \\
\text { or fear of death, as well as the expectations of their relatives regarding their treatment. Request psychological coun- } \\
\text { seling or a Palliative Care team (when evaluated by the physician and requested by him, consisting of nurse, psycholo- } \\
\text { gist, physician, social worker and chaplain (to punctuate only the request). }\end{array}$ & 4.0 & 85.7 \\
\hline $\begin{array}{l}\text { - Support and care for family members and patients require exclusive dedication for } 3 \text { hours or more in } \\
\text { any shift, such as: death, difficult circumstances, such as large numbers of family members, communication } \\
\text { failures, hostile family members. } \\
\text { Patients are considered to be those initiate treatment and receive guidance on the diagnosis, treatment } \\
\text { and course of the disease, and in situations of extreme anxiety of the patient and family, in which a greater } \\
\text { dedication and clarification is required. Nurses qualified in end-of-life care, communication of bad news. }\end{array}$ & 32.0 & 85.7 \\
\hline \multicolumn{3}{|l|}{ 5. Administrative and managerial tasks } \\
\hline $\begin{array}{l}\text { - Performance of routine tasks, such as: processing clinical data, requesting exams, exchange of professional } \\
\text { information (eg, shifts and clinical visits). } \\
\text { It is considered the application of the Nursing Process or protocols that last up to } 1 \text { hour in a continuous or } \\
\text { fractional way. For Example: Sepsis Protocol. }\end{array}$ & 4.2 & 100 \\
\hline $\begin{array}{l}\text { - Perform administrative and managerial tasks that require full dedication for about } 2 \text { hours on some shift, } \\
\text { such as: research activities, protocol application and admission and discharge procedures. } \\
\text { Administrative procedures are considered to transfer the patient to another institution or institution, to } \\
\text { report on occurrences, such as the management of extravasation and/or referral of specific tests, to meet } \\
\text { the demand of the insurers - reports, justification of glosses, among other details. }\end{array}$ & 23.2 & 100 \\
\hline $\begin{array}{l}\text { - Performance of administrative and managerial tasks that require full dedication for about } 4 \text { hours or more } \\
\text { on any shift, such as: death and organ donation procedures and coordination with other disciplines. } \\
\text { It is considered the holding of multiprofessional clinical meetings, consensus meeting and monitoring of } \\
\text { the Permanent Education activities of the team. }\end{array}$ & 30.0 & 100 \\
\hline \multicolumn{3}{|l|}{ Ventilatory support } \\
\hline $\begin{array}{l}\text { 6. Ventilatory support - presence of any form of mechanical ventilation/assisted ventilation with or without positive } \\
\text { end-expiratory pressure, with or without muscle relaxants, spontaneous breathing with or without positive end- } \\
\text { expiratory pressure (ex-CPAP or BiPAP), with or without endotracheal tube, supplemental oxygen, or any method. }\end{array}$ & 1.4 & 100 \\
\hline
\end{tabular}




\begin{tabular}{|c|c|c|}
\hline Basic Activities & Score & $\begin{array}{l}\text { Concordance } \\
\text { Level } \%\end{array}$ \\
\hline $\begin{array}{l}\text { 7. Care with artificial air passages - endotracheal or tracheostomy tube. } \\
\text { Special care is provided for patients with lesions in the nasal and oral cavities and docketed care such as } \\
\text { oral mucositis and dentists' request in general or in specific care, such as in bone marrow transplantation. }\end{array}$ & 1.8 & 100 \\
\hline $\begin{array}{l}\text { 8. Treatment to improve pulmonary function - physiotherapy, stimulated spirometry, inhalation therapy, endotra- } \\
\text { cheal aspiration. } \\
\text { It is considered the accomplishment of the tracheal aspiration and request of accompaniment of physiotherapists } \\
\text { (to punctuate the request). }\end{array}$ & 4.4 & 85.7 \\
\hline \multicolumn{3}{|l|}{ Cardiovascular Support } \\
\hline $\begin{array}{l}\text { 12. Dosage-independent vasoactive medication. } \\
\text { Patient is considered to be those who receive chemotherapy drugs with allergenic potential and mono- } \\
\text { clonal antibodies (e.g, avastim, transtuzumab). Installation and constant change of chemotherapeutic and } \\
\text { administration of fluids for hydration, depending on the drug administered. Patients undergoing cardiotoxic } \\
\text { drugs, such as Doxorubicin, Fluorouracil and Cyclophosphamide. }\end{array}$ & 1.2 & 71.4 \\
\hline $\begin{array}{l}\text { 13. Intravenous replacement of large fluid losses, fluid delivery }>3 \mathrm{l} / \mathrm{m}^{2} / \text { day, regardless of the type of fluid } \\
\text { administered. } \\
\text { Patients are to be considered those receive fluid replacement like the crystalloids, colloids, blood and blood } \\
\text { derivatives routinely. }\end{array}$ & 2.5 & 100 \\
\hline 14. Monitoring of the left atrium. Pulmonary artery catheter with or without cardiac output measurement. & 1.7 & 100 \\
\hline 15. Cardiorespiratory resuscitation in the last 24 hours, excluding precordial thump. & 7.1 & 100 \\
\hline \multicolumn{3}{|l|}{ Renal Support } \\
\hline $\begin{array}{l}\text { 16. Hemophilization and dialytic techniques } \\
\text { It is considered the request of any dialysis modality: continuous peritoneal dialysis or intermittent perito- } \\
\text { neal dialysis. In both cases of renal replacement therapy with any duration (the request being punctuated if } \\
\text { not performed in the unit). }\end{array}$ & 7.7 & 100 \\
\hline $\begin{array}{l}\text { 17. Quantitative measure of oliguria. } \\
\text { Patients are considered to be undergo urinary volume control through spontaneous urination, long-term or } \\
\text { short-term bladder catheter, diaper or sheet weight. Methotrexate, serious magnesium levels (e.g, asparagi- } \\
\text { nase, vincristine and ifosfamide) and in case of nephrotoxic drugs (e.g, cisplatin and interleukin 2). }\end{array}$ & 7.0 & 85.7 \\
\hline \multicolumn{3}{|l|}{ Neurological Support } \\
\hline $\begin{array}{l}\text { 18. Measurement of intracranial pressure. } \\
\text { Patients are considered to be those receive intrathecal chemotherapy and who had bleeding due to thrombocy- } \\
\text { topenia. }\end{array}$ & 1.6 & 85.7 \\
\hline \multicolumn{3}{|l|}{ Metabolic Support } \\
\hline $\begin{array}{l}\text { 19. Treatment of acidosis/complicated metabolic alkalosis. } \\
\text { Patients are considered to be those are in metabolic emergencies, such as acute or chronic hypercalcemia, } \\
\text { tumor lysis syndrome, hyperglycemia, septic shock and ascites. }\end{array}$ & 1.3 & 100 \\
\hline $\begin{array}{l}\text { 20. Intravenous hyperfeeding. } \\
\text { Patients are to be considered those receives parenteral nutrition. }\end{array}$ & 2.8 & 100 \\
\hline $\begin{array}{l}\text { 21. Enteral feeding through a gastric tube or other gastrointestinal tract (e.g, jejunostomy). } \\
\text { Patients are to be considered those with enteral diet. }\end{array}$ & 1.3 & 100 \\
\hline \multicolumn{3}{|l|}{ Special Interventions } \\
\hline $\begin{array}{l}\text { 22. Specific interventions in the ICU: endotracheal intubation, pacemaker insertion, cardioversion, endoscopy, } \\
\text { emergency surgery in the last } 24 \text {-hour period, gastric lavage. Routine interventions without direct consequences } \\
\text { for the clinical conditions of the patient, such as: x-rays, ultrasound, electrocardiogram, dressings or insertion of } \\
\text { venous or arterial catheters, are not included. } \\
\text { It is considered a unit of nursing care and ICU the passage of nasoenteric, vesical, probes, assistance to physi- } \\
\text { cians in myelogram, thorocentesis, collection of liquor and intrathecal medication, PICC (central venous catheter } \\
\text { for peripheral insertion), marrow biopsy, pericardiocentesis and Oncologic Emergencies (e.g superior vena cava } \\
\text { syndrome, spinal cord compression, among others). }\end{array}$ & 2.8 & 71.4 \\
\hline $\begin{array}{l}\text { 23. Specific interventions outside the ICU: diagnostic or surgical procedures } \\
\text { Nursing care unit is considered if there is an ICU including units of Bone Marrow Transplant. Patient } \\
\text { follow-up and transfer, examinations, treatments such as radiotherapy and intravenous catheter. }\end{array}$ & 1.9 & 100 \\
\hline
\end{tabular}




\section{DISCUSSION}

The items of the tool that most suffered changes and contributions by the judges were listed.

Regarding the physiological question, the most altered item was presence at the bedside and observation or continuous activity for 2 hours or more in any shift. The use of long-term venous catheters is fundamental to ensure greater safety in the application of antineoplastic antibiotics, reinforcing that puncture and maintenance of these are exclusive activities of the nursing professional ${ }^{(11)}$.

Another consideration was the: monitoring and controls. Stressing the importance of vital signs in a case report in Taiwan, about a patient with esophageal cancer who underwent radiotherapy, in which he had as a complication a carotid-esophageal fistula. This study has shown the importance of the attention to vital signs and neurological symptoms of patients with cancer to prevent possible complications of radiotherapy $y^{(12)}$.

With regard to pain, in cancer patients, this is beyond the physiological scope. According to a study carried out at the clinical oncology, chemotherapy and radiotherapy units of a general hospital in Rio Grande do Sul with oncology nurses, the need for the caregiver to have the sensitivity and insight to identify the pain correctly and implement actions to manage it ${ }^{(13)}$.

Presence at the bedside and observation or continuous activity for 4 hours or more in any shift; The same importance is given to this extravasation factor, in a study carried out in São Paulo State, in a chemotherapy center, which exemplifies the risk factors of extravasations related to cutaneous vascular fragility, which is common in this group of patients and caused by the nutritional deficit, sclerosing and irritant action of antineoplastic antibiotics and progressive wear of the peripheral venous network and blood transfusion ${ }^{(11)}$.

In a study conducted in California (USA), skin reactions due to the use of cytarabine and antineoplastic antibiotics were observed. Statement and physical examination, with particular attention to predilection areas (armpits, groin, back of the neck, ears and scalp), remain the best tools to differentiate this diagnosis from more severe reactions ${ }^{(14)}$.

Laboratory investigations; Interpretation on pre-chemotherapy laboratory tests is necessary. Such an interpretation requires nurses to have the knowledge and ability to use this information to make clinical decisions regarding the release of chemotherapy or not ${ }^{(11)}$.

Discussing anemia, a multicenter study involving 24 European countries aimed to prospectively assess the prevalence, incidence, and treatment of anemia in European cancer patients. The prevalence of anemia at the time of enrollment was 39.3\% and $67.0 \%$ during the study. Low levels of hemoglobin correlated significantly with poor performance. The incidence of anemia was $53.7 \%$. Anemia was treated in $38.9 \%$ of the patients. The prevalence and incidence of anemia in patients with cancer was high. The recognition of these results may lead to better anemia management, improving the quality of life of these patients ${ }^{(15)}$.

Support and care for family and patients; A study carried out in the palliative care unit of the Hospital Amaral Carvalho in the city of Jaú-SP states that patient and family should be considered as a unit of care and need qualified assistance from the palliative care team, an interdisciplinary team, who through actions, decrease the impact of disease and ensure dignity in the process of dying ${ }^{(16)}$.

Palliative care performed by a specialized team can be noticed in a study carried out in Castilla - La Mancha (Spain), in the Primary Care. The study reinforces the importance of palliative care performed by a team specialized in the issue to obtain quality care in these patients ${ }^{(17)}$.

Support and care for family members and patients who require exclusive dedication for 3 hours or more in any shift; In a study carried out in São Paulo, the objective was to report the care provided to women with cervical cancer and their respective relatives. It showed that it is up to nurses to indicate and provide guidance on preventive measures, guide and follow the patient and their family up, not forgetting their individuality ${ }^{(18)}$.

Cardiovascular support: Independent vasoactive medication; Nurses becomes necessary, as well as their technical ability in the administration of medicines in its various ways, especially intravenous and especially when they apply irritating or blister antineoplastic antibiotics ${ }^{(11)}$.

In a study carried out in Italy on the use of trastuzumab, it emphasizes on the cardiovascular side effects of the cancer treatment. Two categories of cardiotoxic side effects of antineoplastic antibiotics have been proposed: type I cardiotoxicity, defined as permanent and usually caused by anthracyclines; Type II cardiotoxicity, considered reversible, has been mainly related to monoclonal antibodies. The study proposed a new classification for the cardiotoxic effects of drugs used in cancer therapy, as some studies have shown a higher incidence of heart failure and/or cardiomyopathy in patients treated with trastuzumab, which may persist for many years after completion of therapy, suggesting , thus, that the toxic side effects are not always reversible ${ }^{(19)}$.

In an article on Continuing Education conducted in the USA, it is noteworthy that anemia is present in almost $50 \%$ of cancer patients during the disease. Patients with solid tumors undergoing surgery are at increased risk of perioperative anemia due to hemorrhage or surgical hemodilution. Thus, transfusions of blood products can be considered life-saving in some clinical settings; However, there are still several complications that may occur, including viral or bacterial infections, hemolytic reactions, fluid overload, pulmonary lesions, hyperkalemia and immune suppression, thus demonstrating the importance of caution in administration and attention to possible reactions ${ }^{(20)}$.

Renal support: hemofiltration and dialytic techniques; Due to treatment or to the disease itself, the kidney function of patients with cancer may be impaired. In a study carried out in Portugal, the objective was to identify the prognostic determinants of in-hospital mortality of patients with hematological malignancies. The study concluded that the association of mechanical ventilation, septic shock, and allogeneic stem cell treatment was identified as an independent predictor of death in patients with hematological diseases and AKI, with only a small chance of survival if all three were present ${ }^{(21)}$.

Quantitative measure of oliguria; In a study carried out in Mexico, it has been shown that critically ill cancer patients face an increased risk of Acute Kidney Injury (AKI), the most common of which are the risk factors associated with cancer or its treatment. 
The study found that almost $70 \%$ of patients with cancer and critically ill developed AKI. Surveillance of urinary output may increase the sensitivity of detection of AKI patients in $\mathrm{ICU}^{(22)}$.

Special interventions; On the relationship with oncologic urgencies, a study conducted in the USA, aimed at reviewing the most common acute findings and oncologic emergencies that occur in the thorax. The recognition of these phenomena by radiologists is fundamental for accurate diagnosis and timely clinical management ${ }^{(23)}$.

Specific interventions outside the ICU: diagnostic or surgical procedures; On the transfer of patients, a study carried out in a University Hospital in Norway was one of the pioneers in the implementation of electronic messaging between the hospital and the home, in order to facilitate communication between these sectors. Broad communication and information exchange among health professionals in all organizations is therefore required in order to facilitate transitions as smoothly as possible, and health information technologies are being introduced to support these processes ${ }^{(24)}$.

In order to build an effective and sustainable approach to the implementation of Canadian Oncology Symptom Triage and Remote Support (COSTaRS), managerial and administrative tasks, with respect to the nursing protocols used in Oncology, for nurses, providing symptom support via telephone to patients with cancer, evidenced the need for clear organizational alignment and continuous support for nurses to support protocol use ${ }^{(25)}$.

Performance of administrative and managerial tasks that require full dedication for about 2 hours in any shift; Transfers between hospitals were discussed in a USA study aimed at assessing the integrity and timeliness of information transfer and communication between a tertiary-level academic hospital and its post-acute care facilities. There was a substantial deficit in the content and timing of transfers between hospitals and facilities ${ }^{(26)}$.

A study carried out in a university hospital in the south of the country, had as objective to know the significant learning experiences of nurses facilitating Permanent Education actions in the hospital context and to analyze the implications of this learning in the transformation of their health care practices. Finally, the existence of a Permanent Education program at the hospital level promotes the construction of strengthened groups, since it increases the possibility of implementing the changes aimed at in-service education actions ${ }^{(27)}$.

Still in relation to the Nursing Activities Score tool, it is able to measure the workload of the nursing staff with greater precision than the resolutions used for personnel sizing, such as Resolution of Anvisa RDC N 7 of 2010, as exemplified in a study carried out in the Instituto da Criança (freely translated as Institute of the Child) of the Hospital das Clínicas (Clinics Hospital) of the Faculdade de Medicina of the Universidade de São Paulo (HCFMUSP), in neonatal unit ${ }^{(28)}$.

The quality of care can be evidenced through a study conducted in the Netherlands to better understand how feedback from nursing teams on quality measures affects the well-being and performance of nurses. Supporting nursing staff in team reflection after receiving feedback on quality measures can help to gain positive perceptions among nurses and thereby create positive feedback effects on their well-being and performance ${ }^{(29)}$.

Patient safety is a constant challenge for health institutions and for health care training schools. In 2011, WHO launched the WHO patient safety curriculum guide: multi-professional edition, which brings all the effort focused on knowledge, skills and attitudes/ behaviors required of all health professionals (WHO, 2011). The $\mathrm{WHO}$ proposes that teaching the subject can integrate the existing curriculum and how it can be developed by teachers and students ${ }^{(30)}$.

\section{Study limitations}

The limitation of this study is the non-application of the tool with patients with cancer, which is explained by the lack of time during the master's course. Thus, the suggestion is to apply it in several oncology units.

Contributions to the area of nursing, health or public policy

The Nursing Activities Score adapted to Oncology is a tool that can assist in measuring the workload of the nursing team in Oncology, which can contribute to the personnel dimensioning and improve the planning of interventions to meet the demands of care of the patients with cancer.

\section{FINAL CONSIDERATIONS}

The Nursing Activities Score (NAS) content was adapted for nursing care in Oncology and a high level of oncology patient complexity and the demand for care and biopsychosocialspiritual care were observed.

Therefore, the tool can help in the dimensioning of the nursing team and in the planning of interventions to meet the care demands of cancer patients, and may interfere in the quality of care to these patients, and studies such as these could influence others, knowledge in this area.

\section{REFERENCES}

1. Instituto Nacional do Câncer. O que é o câncer? [Internet]. [nd] [cited 2014 Jul 15]. Available from: http://www1.inca.gov.br/ conteudo_view.asp?id=322

2. Herr GE, Kolankiewicz ACB, Berlezi EM, Gomes JS, Magnago TSBS, Rosanelli CP, et al. Avaliação de conhecimentos acerca da doença oncológica e práticas de cuidado com a saúde. Rev Bras Cancerol [Internet]. 2013[cited 2014 Jul 15];59(1):33-41. Available from: http://www1.inca.gov.br/rbc/n_59/v01/pdf/06-avaliacao-de-conhecimentos-acerca-da-doenca-oncologica-e-praticas-decuidado-com-a-saude.pdf

3. São Paulo. Conselho Regional de Enfermagem. Parecer COREN - SP 027/2012 - CT. São Paulo; 2012 [cited 2014 Jul 15]. Available from: http://portal.corensp.gov.br/sites/default/files/parecer_coren_sp_2012_27.pdf 
4. Novaretti MCZ, Santos EV, Quitério LM, Gallotti RMD. Sobrecarga de trabalho da Enfermagem e incidentes e eventos adversos em pacientes internados em UTI. Rev Bras Enferm [Internet]. 2014[cited 2014 Jul 15];67(5):692-9. Available from: http://www.scielo. br/pdf/reben/v67n5/0034-7167-reben-67-05-0692.pdf

5. Padilha KG, Sousa RMC, Miyadahira AMK, Cruz DALM, Vattimo MFF, Kimura M, et al. Therapeutic intervention scoring system-28 (TISS-28): diretrizes para aplicação. Rev Esc Enferm USP[Internet]. 2005[cited 2014 Jul 15];39(2):229-33. Available from: http:// www.scielo.br/pdf/reeusp/v39n2/14.pdf

6. Reich R, Vieira DFVB, Lima LB, Silva ERR. Nursing workload in a coronary unit according to the Nursing Activities Score. Rev Gaúcha Enferm[Internet]. 2015[cited 2014 Jul 15];36(3):28-35. Available from: http://seer.ufrgs.br/index.php/RevistaGauchadeEnfermagem/ article/download/51367/35046

7. Camuci MB, Martins JT, Cardeli AAM, Robazz MLCC. Nursing Activities Score: nursing work load in a burns Intensive Care Unit. Rev Latino-Am Enfermagem[Internet]. 2014[cited 2014 Jul 15];22(2):325-31. Available from: http://www.scielo.br/pdf/rlae/ v22n2/0104-1169-rlae-22-02-00325.pdf

8. Lindeman CA. Delphi survey of priorities in clinical nursing research. Nurs Res. 1975;24(6):434-41.

9. Wright JTC, Giovinazzo RA. Delphi: uma ferramenta de apoio ao planejamento prospectivo. Cad Pesqui Adm[Internet]. 2000[cited 2014 Jul 15];1:54-65. Available from: http://bdpi.usp.br/single.php?_id=001173053

10. Beaton D, Bombardier C, Guillermin F, Ferraz MB. Recomendations for the Cross-Cultural Adaptation of the DARS \& QuickDash Outcome Measures. Institute For Work \& Health and Institute de Recherche Sur Le travail et La Santé. Revised June 12, 2007. 45p.

11. Souza CA, Jérico MC, Perroca MG. Nursing intervention/activity mapping at a Chemotherapy Center: an instrument for workload assessment. Rev Latino-Am Enfermagem[Internet]. 2013[cited 2014 Jul 15];21(2):[08 telas]. Available from: https://www.revistas. usp.br/rlae/article/download/75949/79433

12. Kuo KH, Hsu HL, Pan YJ, Huang CY. Carotid blowout and cerebral gas embolism related to bidirectional carotid-esophageal fistula: a serious complication of esophageal cancer under radiotherapy. Am J Emerg Med[Internet]. 2016[cited 2014 Jul 15];34(3):683. e5-6. Available from: https://www.ncbi.nlm.nih.gov/pubmed/26349780

13. Stübe M, Cruz CT, Benetti ERR, Gomes JS, Stumm EMF. Percepções de enfermeiros e manejo da dor de pacientes oncológicos. Rev Min Enferm[Internet]. 2015[cited 2014 Jul 15];19(3):696-703. Available from: http://www.reme.org.br/artigo/detalhes/1033

14. Ruben BS, Yu WY, Liu F, Truong SV, Wang KC, Fox LP. Generalized benign cutaneous reaction to cytarabine. J Am Acad Dermatol[Internet]. 2015[cited 2014 Jul 15];73(5):821-8. Available from: https://www.ncbi.nlm.nih.gov/pubmed/26321388

15. Heinz Ludwig H, Belle SV, Barrett-lee P, Birgegård G, Bokemeyer C, Gascón P, et al. The European Cancer Anaemia Survey (ECAS): a large, multinational, prospective survey defining the prevalence, incidence, and treatment of anaemia in cancer patients. Eur J Cancer[Internet]. 2004[cited 2014 Jul 15];40(15):2293-306. Available from: https://linkinghub.elsevier.com/retrieve/pii/ S0959-8049(04)00511-8

16. Capello EMCS, Velosa MVM, Salotti SRA, Guimarães HCQCP. Enfrentamento do paciente oncológico e do familiar/cuidador frente à terminalidade de vida. J Health Sci Inst[Internet]. 2012[cited 2014 Jul 15];30(3):235-40. Available from: https://www.unip.br/ presencial/comunicacao/publicacoes/ics/edicoes/2012/03_jul-set/V30_n3_2012_p235a240.pdf

17. Carnero RG, Nava JGS, Pilicita FEC, Suanes GG, Germán PPR, Castro FL. Necesidades formativas en la atención a pacientes oncológicos en Castilla-La Mancha. Med Paliat[Internet]. 2013[cited 2014 Jul 15];20(3):103-10. Available from: scielo.isciii.es/ pdf/albacete/v4n3/original1.pdf

18. Frigato S, Hoga LAK. Assistência à mulher com câncer de colo uterino: o papel da enfermagem. Rev Bras Cancerol[Internet]. 2003[cited 2014 Jul 15];49(4):209-14. Available from: www.inca.gov.br/rbc/n_49/v04/pdf/ARTIGO1.pdf

19. Riccioa G, Coppola C, Piscopo G, Capasso I, Maurea C, Esposito E, et al. Trastuzumab and target-therapy side effects: is still valid to differentiate anthracycline Type I from Type II cardiomyopathies? Hum Vaccin Immunother[Internet]. 2016 [cited 2014 Jul 15];12(5):1124-31. Available from: https://www.ncbi.nlm.nih.gov/pmc/articles/PMC4963071/

20. Velásquez JF, Cata JP. Transfusions of blood products and câncer outcomes: continuing education. Rev Esp Anestesiol Reanim[Internet]. 2015[cited 2014 Jul 15];62(8):461-7. Available from: https://www.ncbi.nlm.nih.gov/pubmed/25896733

21. Chuva T, Maximino J, Barbosa J, Silva S, Paiva A, Baldaia J, et al. Haematological malignancies and acute kidney injury requiring nephrology consultation: challenging the worst of the worst. Clin Kidney J[Internet]. 2016[cited 2014 Jul 15];9(3):418-23. Available from: https://www.ncbi.nlm.nih.gov/pmc/articles/PMC4886918/

22. Sánchez BMC, Gómez AH, Silva SAN. Acute kidney injury classified by serum creatinine and urine output in critically ill cancer patients. Biol Med Res Int[Internet]. 2016[cited 2014 Jul 15];(2016):6805169. Available from: http://dx.doi.org/10.1155/2016/6805169

23. Carter BWMD, Erasmus JJMD. Acute thoracic findings in oncologic patients. J Thorac Imaging[Internet]. 2015 [cited 2014 Jul 15];30(4):233-46. Available from: https://www.ncbi.nlm.nih.gov/pubmed/25803363

24. Melby L, Brattheim JB, Helleso R. Patients in transition-improving hospital-home care collaboration through electronic messaging: providers' perspectives. J Clin Nurs[Internet]. 2015[cited 2014 Jul 15];24(23-24):3389-99. Available from: https://www.ncbi.nlm. nih.gov/pubmed/26374139

25. Stacey D, Green E, Ballantyne B, Tarasuk J, Skrutkowski M, Carley M, et al. Implementation of Symptom Protocols for Nurses 
Providing Telephone-Based Cancer Symptom Management: a comparative case study. Worldviews Evid Based Nurs[Internet]. 2016[cited 2014 Jul 15];13(6):420-31. Availabre from: https://sigmapubs.onlinelibrary.wiley.com/doi/abs/10.1111/wvn.12166

26. Jones CD, Cumbler E, Honigman B, Burke RE, Boxer RS, Levy C, et al. Hospital to post-acute care facility transfers: identifying targets for information exchange quality improvement. J Am Med Dir Assoc[Internet]. 2017[cited 2014 Jul 15];18(1):70-3. Available from: https://www.ncbi.nlm.nih.gov/pubmed/27815110

27. Flores GE, Oliveira DLL, Zocche DAA. Educação permanente no contexto hospitalar: a experiência que ressiginifica o cuidado em enfermagem. Trab Educ Saúde[Internet]. 2016[cited 2014 Jul 15];14(2):487-504. Available from: http://www.scielo.br/pdf/tes/ v14n2/1678-1007-tes-1981-7746-sip00118.pdf

28. Nunes BK, Toma E. Assessment of a neonatal unit nursing staff: application of the Nursing Activities Score. Rev Latino-Am Enfermagem[Internet]. 2013[cited 2014 Jul 15];21(1):[08 telas]. Available from: https://www.revistas.usp.br/rlae/article/view/52961/56989

29. Giesbers SAPM, Schouteten RLJ, Van der Hejiden BIJM, Van Achterberg T. Nurses' perceptions of feedback to nursing teams on quality measurements: an embedded case study design. Int J Nurs Stud[Internet]. 2016[cited 2014 Jul 15];64:A1-4, 1-142. Available from: https://www.ncbi.nlm.nih.gov/pubmed/27768986

30. World Health Organization-WHO. Who Patiente Safety curriculum guide: multi-professional edition [Internet]. Genebra: WHO; 2011 [cited 2014 Jul 15]. Available from: http://www.who.int/patientsafety/education/mp_curriculum_guide/en/ 